\title{
Individual Religiosity and Orientation towards Science: Reformulating Relationships
}

\author{
David R. Johnson, ${ }^{a}$ Christopher P. Scheitle, ${ }^{b}$ Elaine Howard Ecklund ${ }^{a}$
}

a) Rice University; b) St. John's University

Abstract: The religion-science relationship has been the focus of a growing body of research. Such analyses have often suffered from poorly specified concepts related to religion and to science. At the individual level, scholars often assume that an individual's religiosity will affect her orientation towards science. But an orientation towards science consists of several sub-concepts, each of which may have a unique relationship, or lack thereof, with religiosity. We use observed measures from the 2008 General Social Survey to build latent variables representing science orientation sub-concepts and assess their relationships using structural equation modeling. We find that religiosity has no significant association with interest in or knowledge of science. Religiosity does, however, have a significant negative association with confidence in science. This suggests that the lack of faith in science held by religious individuals is not a product of interest or ignorance, but is instead based on theological or institutional reservations.

Keywords: religion; science; conflict; public understanding of science; structural equation modeling

Citation: Johnson, David R., Christopher P. Scheitle and Elaine Howard Ecklund. 2015. "Individual Religiosity and Orientation towards Science: Reformulating Relationships." Sociological Science 2: 106-124.

Received: November 18, 2014

Accepted: December 1, 2014

Published: March 11, 2015

Editor(s): Jesper Sørensen, Sarah Soule

DOI: 10.15195/v2.a7

Copyright: (C) 2015 The Author(s). This open-access article has been published under a Creative Commons Attribution License, which allows unrestricted use, distribution and reproduction, in any form, as long as the original author and source have been credited. (0)(1)
SOCiological research into the religion-science relationship has been described $\mathcal{S}$ as "one of the muddiest in all of sociology" (Evans and Evans 2008:88). Much of this muddiness is due to a lack of conceptual clarity, and while operationalization of religion and science is complex, it is often science that receives less attention in such conceptualizations. While scholars often distinguish among different aspects of religion, measuring religious beliefs, behaviors, identities and organizational affiliations, they often do not effectively deconstruct what is meant by "science." This lack of conceptual clarity naturally produces a lack of measurement specificity in analyses.

One approach to understanding the religion-science relationship effectively controls for variation in the meaning or dimensions of science by studying religion in science-based professions (see Ecklund 2010; Ecklund and Scheitle 2007; Ecklund, Park, and Veliz 2008; Cadge, Ecklund, and Short 2009; Ecklund and Park 2009; Gross and Simmons 2009). ${ }^{1}$ A primary motivation of these studies is to understand how members of the largely secular culture-producing institution of science understand the relationship between religion and science. In this context, the theoretical emphasis is on how highly scientific individuals are oriented to religion.

The religious beliefs of scientists, however, are not indicative of those of the general population (Ecklund and Scheitle 2007). Research on how the general public views science has relied on survey research to understand individual-level orientation towards science, but too often this topic suffers from overly broad or poorly specified concepts. Although scholars have specified distinctive types of conflict between religion and science (Evans 2011), current research tends to 
operationalize science as an umbrella concept, often as a component of a dependent variable that assesses perceptions of the relationship between science and religion. Scheitle (2011), for example, examines how numerous dimensions of religiosity shape college students' perceptions of whether science and religion are conflicting, independent, or collaborative. Baker (2012) pursues a similar strategy. Survey questions in both studies measure perceived conflict between science and religion (e.g., agreement with the statement "Science and religion are incompatible") that take for granted the meaning(s) or conceptual dimensions of science.

Existing work underspecifies different dimensions that could contribute to an individual's orientation towards science; interest in, consumption of, knowledge of, and confidence in science are all potential components of an "orientation towards science" concept. Existing models and empirical tests of the religion-science relationship have constrained our ability to measure whether and how these subconcepts of individual orientation are interrelated, and with what implications for the religion-science relationship. This is primarily because of the common use of scaled variables that cluster together conceptually distinct constructs (such as awareness of science and knowledge of science), without any analysis of the content of the items and their theoretical and conceptual commonality. Consequently, it is difficult to derive hypotheses about causal relationships between dimensions of science and religion.

In the research presented here we contribute to the existing literature in two ways. First, we specify the distinct subcomponents of an individual's orientation to science and consider the ways in which each component may be related to religion. In doing so, we highlight how the different ways scholars have operationalized science as well as orientation towards science often combine conceptually distinct measures. Furthermore, much of the previous research on individual religiosity and orientation towards science has focused on "net" or direct effects. Such a focus masks potentially significant indirect effects but, more importantly, masks the process through which religiosity shapes orientation towards science. For instance, an analysis may find that, net of an individual's knowledge of science, religiosity does not affect confidence in science-but what if religiosity affects knowledge of science, which itself affects confidence in science? In short, ignoring either the distinct components of orientation towards science or the direct and indirect paths between those concepts distorts our understanding of religiosity's role in shaping orientation towards science.

Drawing on data from the 2008 General Social Survey and using structural equation modeling, we present a model that illustrates the specific mechanisms through which an individual's religiosity affects their orientation towards science. We begin by identifying and highlighting the distinctive nature of each dimension of scientific orientation and how each may be related to individual religiosity.

\section{Science and Scientific Orientation}

Discussions of how science should be conceptualized have provoked cautionary tones from both classic and contemporary sociologists of science (Gieryn 1983; Merton 1968). The conceptual difficulty does not decrease when we move away 
from trying to define science in the abstract and instead try to define an individual's orientation towards science, because orientations to science are multidimensional. One's confidence in or skepticism of aspects of science, for example, is shaped by interest in science, consumption of science, and knowledge of science. In discussing how religion shapes one's orientation towards science, we must consider all of these subconcepts. We focus on four subconcepts that stand out in previous research and theory (see Miller 1991; Nisbet 2005; Gauchat 2008; Brossard et al. 2009; Evans 2011; National Science Board 2012): interest, consumption, knowledge, and confidence.

\section{Interest in Science}

In thinking about an individual's orientation towards science, interest levels might be what most people think of first, perhaps because interest levels are seen as a prerequisite for any other scientific orientation. That is, if a person has low interest in science then they will be less likely to consume scientific information. For example, an individual who is not interested in new scientific discoveries is unlikely to visit a science museum or watch popularized accounts of science such as Carl Sagan's Cosmos. Possibly because of this perception of interest level as key to driving other scientific outcomes, much social policy research has been aimed at increasing levels of interest, particularly among youth (Boullion and Gomez 2001; Brickhouse 1994), marginalized groups (Lee and Fradd 1998), and women (Correll 2001; Kelly 1985). While there are clearly variations in interest levels across social and demographic variables, the majority of the U.S. public declares moderate to great interest in new scientific discoveries (National Science Board 2012).

If religion affects an individual's orientation towards science, it could be that its effect on interest levels is a key factor to specify. But only indirect evidence is available on religion's effect on interest in science, primarily from studies that include interest as one part of a broader composite measure of orientation to science. Studying religious opposition to embryonic stem cell research, for example, Nisbet (2005) includes the commonly used "issue public" measure, which is a composite of awareness of and interest in new scientific discoveries and new medical discoveries. Such a composite may confound what could be distinctive relationships between religion and interest versus religion and awareness. Nisbet (2005) shows that being a part of the issue public increases support for stem cell research, but he did not analyze interest by itself or whether being part of the issue public is moderated by religion. Dragojlovic and Einsiedel (2012) also employ a composite measure that includes interest in science in their study of religious beliefs and approval of synthetic biology. Their measure, "scientific awareness," is a composite measure of two indices - an ability index and a motivation index. The motivation index comprises four types of activism related to science, and interest in new scientific discoveries, environmental problems, and new medical discoveries. The ability index represents the extent to which respondents are informed on science, the environment, and medicine, as well as the respondents' levels of education. The two indices are multiplied together to express scientific awareness. Dragojlovic and Einsiedel (2012) show that scientific awareness moderates the impact of belief in God on attitudes towards synthetic biology only among individuals with the 
highest levels of awareness. While the measure they employ may adequately assess awareness of science, it is unable to isolate the relationship between interest in science and religiosity. ${ }^{2}$

In the absence of studies of the direct effect of religiosity on interest in science, there is no straightforward assumption that can be offered. The "epistemological conflict narrative" (Evans and Evans 2008) suggests that science and religion employ different ways of knowing the world and consequently, those exposed to religion are less likely to pursue scientific knowledge. This suggests a negative association between personal religiosity and interest in science. Yet Evans (2011) provides some support to indicate that religious individuals do not differ from nonreligious individuals in their propensity to seek out scientific knowledge. To be sure, Evans (2011) operationalizes propensity for scientific knowledge not with measures of interest, but through measures such as knowledge of scientific facts and whether or not individuals claim knowledge about science. These variables are indicative of knowledge of science, but not necessarily of interest in it. In examining individuals' propensity to major in science or engineering or to work in a scientific occupationwhich are effective measures of interest in science-Evans (2011) finds no differences between religious and nonreligious groups.

\section{Consumption of Science}

Consumption of science refers to the extent to which individuals seek and utilize scientific knowledge. It is not a straightforward construct, due to the ubiquity of science in life. Science is integrated into material products that individuals consume and processes they experience, but such consumption is rarely experienced in a context unencumbered by imputed interest or background expectations (Wynne 1991; Yearley 2000).

Although consumption of science and interest in science may be related, individuals may consume science for reasons other than, or even without, interest. For instance, structural differences in society often mediate the consumption of science. Socioeconomic differences structure access to healthcare, such that poor and working class individuals receive less exposure to scientific expertise than middle or upper class individuals (Kirby and Kaneda 2005). Reproduction of inequality in the educational system (Condron and Roscigno 2003) structures access to postsecondary education (Hearn 1991), and thus exposure to science in the educational system varies by class in both high school and college. In short, members of lower socioeconomic strata may have lower consumption of science.

Education provides one perspective on the relationship between religion and consumption of science, but it is an imperfect measure because taking science courses in high school and college is often a product of standardized curricula and not necessarily an individual desire to consume science. One hypothesis is that greater consumption of scientific knowledge causes skepticism of religion, but recent studies call into question this argument. Smith and Snell (2009) find that college-attending students are more likely to be religious than nonattending peers. Using General Social Survey data, Evans (2011) finds that evangelicals take more college-level science classes than nonreligious individuals. And Scheitle (2011) 
finds no evidence that students in the natural sciences experience a greater decrease in religious belief compared to students who "consume" fewer science courses as undergraduates. Hill (2011), by contrast, finds that while college graduates are more favorably disposed to institutionalized religion, skepticism of super-empirical entities (e.g., belief in an afterlife) increases as a result of college attendance and graduation.

Other evidence on consumption of science and religion is less direct. Examining religiosity and support for nanotechnology, Brossard et al. (2009) find that "newspaper science news use" and "television science news use" increase support for nanotechnology, but they do not measure interactions between news use and religiosity. Nisbet (2005) measures awareness of stem cell research (how much one has seen, read, or heard about medical research involving embryonic stem cells) and finds that among highly religious individuals, opinions of stem cell research remain relatively the same even as awareness increases (Nisbet 2005).

\section{Knowledge of Science}

Knowledge of science or apprehension of basic scientific facts, methods, and developments, or scientific literacy, has been extensively measured. Knowledge of science is central to the "deficit model," which posits that "lacking a proper understanding of the relevant facts, people fall back on mystical beliefs or irrational fears of the unknown" (Sturgis and Allum 2004:57). Evans and Evans (2008) show that substantive definitions of religion have essentially described religion as concerning "irrationalities." Thus, the deficit model's emphasis on "mystical beliefs" and "irrational fears" implies that religious people have more mystical beliefs and therefore will possess anti-science attitudes or distrust of the scientific community.

A great deal of research has examined the relationship between scientific knowledge and attitudes toward science, but only a limited number of studies directly consider the relationship between knowledge of science and religion. Higher levels of scientific literacy are associated with positive views of science (Besley and Shanahan 2005; Miller, Pardo, and Niwa 1997), but the statistical relationships are often weak and explain only abstract notions of science, such as its influence on the pace of change in life (Allum et al. 2008; Gauchat 2008). Religion is often included as a control variable in such studies, and the results generally show that scientific knowledge has a more powerful impact on one's attitude toward science than does religion (Scheufele et al. 2008; Gauchat 2008; Sturgis and Alum 2004; Hayes and Tariq 2000). These studies, however, do not assess whether religiosity moderates the effect of scientific knowledge; they only reveal that religiosity has a weak mediating role.

Of the core studies that examine conflict between religion and science, there are four analyses that provide insight into the relationship between knowledge of science and religion. Ho, Brossard, and Scheufele (2008) find that knowledge of science has no significant main effect on support for embryonic stem cell research, but the influence of knowledge is significantly weaker for individuals with high levels of religiosity than for those with low levels of religiosity. In other words, the moral disposition of highly religious individuals overrides the potentially positive 
effects of scientific knowledge (Ho, Brossard, and Scheufele 2008). Brossard et al. (2008) similarly find that highly religious individuals show the lowest levels of support for funding for nanotechnology and that being more knowledgeable does little to influence their support. Among less religious individuals, higher levels of knowledge about nanotechnology strongly influence support for funding. The moderating effect of religion on scientific knowledge suggests that religious considerations may act as a perceptual lens (Scheufele et al. 2008) that helps make sense of what one knows about general or specific scientific issues.

Two studies of epistemological conflict between religion and science paint a mixed picture of the relationship between religion and scientific knowledge. Evans (2011) uses measures of scientific literacy as dependent variables to evaluate denominational variation in disagreement with scientific facts. The study suggests that claims about epistemological conflict between religion and science are overstated because members of most denominations are just as knowledgeable about science as nonreligious individuals. On a select number of scientific claims that appear to conflict with central tenets of certain religions—such as origins of humans-religious individuals believe in their religion more than science. Sherkat (2011) finds, by contrast, that conservative Protestants, Catholics, and fundamentalists have significantly lower levels of scientific literacy relative to nonreligious Americans. ${ }^{3}$

\section{Confidence in Science}

Confidence in science refers to public trust in organized science, scientific knowledge, and the benefits of scientific research. Some scholars suggest that little knowledge of scientific facts and methods leads individuals to embrace anti-modern worldviews that are characterized by superstition, fear, and conspiracy (Holton 1993), while others argue that few individuals actually possess attitudes toward science (Miller 1991). Yet tests and meta-analyses of the knowledge-confidence model suggest weak support for the relationship between factual knowledge and confidence in science (Evans and Durant 1995; Sturgis and Allum 2004; Allum et al. 2008). Recent studies have found that unfavorable views of science are derived from institutional alienation and reservations about bureaucratic authority, and that scientific knowledge helps explain general attitudes toward the scientific community, but not attitudes towards specific science policies (Gauchat 2008). Individuals often distrust scientists but support scientific research (Evans 2012).

Research on the connection between religion and confidence in science shows that conservative Protestants are more skeptical of the benefits of scientific progress than other individuals in society (Ellison and Musick 1995; Gauchat 2008). Strength of devotion, as measured by church attendance and frequency of prayer, is a key contributor to anti-science attitudes (Gauchat 2008). Indeed, confidence in the scientific community in the United States has not declined in the past four decades except among conservatives and individuals who frequently attend church (Gauchat 2012). Studying support for stem cell research, Nisbet (2005) finds that confidence in science mediates the negative effect of religion. These findings suggest, as Shapin (2008) argues, that confidence in scientists and science are different and often opposed. Indeed, Evans (2012) interviewed 62 individuals from various religious 
traditions asking respondents if they would support a hypothetical moratorium on basic scientific research. He finds that religious individuals almost invariably support science (oppose a moratorium), despite moral and ethical concerns about the actions of scientists.

\section{Data and Methods}

To assess the relationships between the different science orientation concepts described above, we use the 2008 General Social Survey (GSS), a nationally representative sample of U.S. adults, which contained several items representing each of the latent concepts we identified above, with one exception. ${ }^{4}$ Possible measures of science consumption in the GSS are, at best, weak proxies. ${ }^{5}$ We therefore did not include consumption in our model. We employ structural equation modeling, which facilitates the creation of latent concepts based on observed variables. ${ }^{6}$ Structural equation modeling also allows for the building and assessment of a theoretical model of direct and indirect effects between observed and latent variables using a series of simultaneous equations. Our analysis is weighted by the WTSSNR weight provided in the GSS. This weight adjusts for the sub-sampling of non-respondents, the number of adults in the household (which affects the likelihood of an individual respondent being selected), and the differential non-response rates across areas. We excluded cases that had missing data on any of our observed measures, which reduced the analytical sample to 612 cases, as some of the measures were only asked for part of the GSS sample.

\section{Scientific Interest}

We measure the latent concept of scientific interest through three items. Each of these items asked, "Are you very interested, moderately interested, or not at all interested in issues about..." The three items of interest were: scientific discoveries; new inventions and technologies; and space exploration. These three questions were part of a larger series of ten public interest questions. ${ }^{7}$ An exploratory factor analysis identified these three items as potentially representing some underlying concept, which we have identified as scientific interest. The items have been reverse coded so that higher scores represent higher levels of interest. The factor loadings for these three items on the latent interest in science variable are $0.73,0.69$, and 0.62 , respectively.

\section{Scientific Knowledge}

We measure individuals' knowledge of science as a latent concept measured by seven observed variables. These variables were part of a true-false science quiz included on the 2008 GSS. The questions were prefaced by, "Now, I would like to ask you a few short questions like those you might see on a television game show. For each statement that I read, please tell me if it is true or false. If you don't know or aren't sure, just tell me so, and we will skip to the next question. Remember true, false, or don't know." The questions were: 
- First, the center of the earth is very hot. Is that true or false?

- All radioactivity is manmade.

- It is the father's gene that decides whether the baby is a boy or a girl.

- Lasers work by focusing sound waves.

- Electrons are smaller than atoms.

- Antibiotics kill viruses as well as bacteria.

- Now, does the Earth go around the Sun, or does the Sun go around the Earth? ${ }^{8}$

There were other questions in this quiz, but they appeared to touch on issues that at least some would view as religiously relevant (e.g., are humans evolved from animals, did the universe begin with a big bang, do the continents drift); to avoid reading lack of agreement as lack of knowledge, we exclude these items.

All of the variables are coded so the correct answer is higher. Following previous research (Evans 2011), we code "Don't know" and "No answer" as an incorrect answer. The factor loadings for the seven employed items on the latent knowledge of science variable are $0.28,0.24,0.16,0.30,0.40,0.32$ and 0.41 , respectively. We would expect these coefficients to be somewhat lower than those of the other latent variables. While there is a clearer connection between attending religious services and seeing oneself as religious, pieces of scientific knowledge are more distinct. That is, a person might know something about lasers and radioactivity but little about viruses and genes. Still, the combined measures represent overall knowledge. ${ }^{9}$

\section{Confidence in Science}

We measure confidence in science as a latent variable represented by three observed variables. Two of these items asked respondents to provide a "strongly agree," "agree," "neither agree or disagree," "disagree," or "strongly disagree" response to the statements: "Overall, modern science does more harm than good;" and "Because of science and technology, there will be more opportunities for the next generation." The third item was part of a series of questions asking about the respondent's confidence in a series of institutions: "As far as the people running these institutions are concerned, would you say you have a great deal of confidence, only some confidence, or hardly any confidence at all in them?" We use the item that asked the respondent's confidence in the "scientific community." All three of these items have been recoded so that higher scores represent higher levels of confidence in science. The standardized factor coefficients of these three items on the latent confidence in science variable are $0.55,0.45$, and 0.45 , respectively. Although we are sensitive to the distinctions prior work has drawn between confidence in science and confidence in scientists (Shapin 2008), the similar factor loadings of the individual measures suggests that they are not as distinct as one might assume. It could be that the "scientific community" item is not interpreted as describing trust in scientists individually. ${ }^{10}$ 


\section{Religiosity}

We measure a person's religiosity through two items. The first item asks, "How often do you attend religious services?" Respondents were given nine possible responses ranging from "never" to "more than once a week." The second item asks, "To what extent do you consider yourself a religious person? Are you very religious, moderately religious, slightly religious, or not religious at all?" The items are coded so that higher scores represent higher levels of religiosity. The standardized factor coefficients of these two items on the latent religiosity variable are 0.74 and 0.71 , respectively. Some researchers suggest biblical literalism is important to the science-religion relationship, but as Roos (2012) shows, the GSS measure of biblical literalism loads significantly with some measures of the science knowledge scale, meaning that including it could bias our results. Biblical literalism is also about a specific type of belief more than general religiosity, which is the main focus of this paper.

\section{Controls}

We include several observed variables as controls. First, we include the respondent's sex, which is coded as $0=$ male and $1=$ female. We also include the respondent's age, which is measured on a continuous basis, with the exception that 89 represents " 89 and older." Respondent's education is measured on a 20-point scale, ranging from "no formal schooling" to "eight years of college." Finally, we include a series of items representing the religious tradition of the respondent's denomination. These items were constructed using the RELTRAD classification (Steensland et al. 2000). ${ }^{11}$

Descriptive statistics for all of the observed measures included in the analysis below are shown in Table 1.

\section{Results}

Our analytical model is shown in Figure 1. Table 2 shows the standardized results from the structural components of the model. Outcomes in the model are shown in the columns of the table, while predictors are shown on the rows. Looking first at the religiosity outcome, we find that neither education nor gender have a significant relationship with this latent concept. Older respondents, however, show significantly higher religiosity scores. Not surprisingly, all of the religious traditions show significantly higher levels of religiosity compared to those with no religious tradition. Of those with a religious tradition, conservative Protestants show the highest levels of religiosity, while Jewish respondents show the lowest.

Examining the interest in science latent variable, we find that religiosity does not have a significant effect on this concept. Of course, it is possible that a person could be interested in a topic but simultaneously hostile towards it. That is, a highly religious person could be just as interested in science as anyone else, but there might be a very different motivation underlying that interest than for a highly irreligious or less religious person. We can assess this later through the confidence outcome. Looking at the religious tradition measures, we see that the 
Table 1: Descriptive Statistics for Observed Measures Used in Analytical Model.

\begin{tabular}{|c|c|c|c|c|}
\hline & Mean & SE & Min & Max \\
\hline \multicolumn{5}{|l|}{ Religiosity } \\
\hline Religious person & 2.58 & 0.04 & 1 & 4 \\
\hline Attendance & 3.52 & 0.13 & 0 & 8 \\
\hline \multicolumn{5}{|l|}{ Interest in science } \\
\hline Science & 2.27 & 0.03 & 1 & 3 \\
\hline Space & 1.88 & 0.03 & 1 & 3 \\
\hline Technology & 2.33 & 0.03 & 1 & 3 \\
\hline \multicolumn{5}{|l|}{ Knowledge of science } \\
\hline Hot core & 1.86 & 0.01 & 1 & 2 \\
\hline Boy or girl & 1.64 & 0.02 & 1 & 2 \\
\hline Electron & 1.52 & 0.02 & 1 & 2 \\
\hline Earth moves & 1.71 & 0.02 & 1 & 2 \\
\hline Radioactivity & 1.81 & 0.01 & 1 & 2 \\
\hline Lasers & 1.77 & 0.02 & 1 & 2 \\
\hline Viruses & 1.64 & 0.02 & 1 & 2 \\
\hline \multicolumn{5}{|l|}{ Confidence in science } \\
\hline Science harms & 3.72 & 0.04 & 1 & 5 \\
\hline Next generation & 3.28 & 0.02 & 1 & 4 \\
\hline Scientific community & 2.33 & 0.02 & 1 & 3 \\
\hline \multicolumn{5}{|l|}{ Religious tradition } \\
\hline Conservative Protestant & 0.23 & 0.01 & 0 & 1 \\
\hline Liberal/moderate Protestant & 0.14 & 0.01 & 0 & 1 \\
\hline Black Protestant & 0.06 & 0.01 & 0 & 1 \\
\hline Catholic & 0.30 & 0.02 & 0 & 1 \\
\hline Jewish & 0.01 & 0.004 & 0 & 1 \\
\hline Other religion & 0.06 & 0.01 & 0 & 1 \\
\hline No religion & 0.17 & 0.01 & 0 & 1 \\
\hline Education & 13.47 & 0.13 & 0 & 20 \\
\hline Age & 45.50 & 0.75 & 19 & 89 \\
\hline Female & 0.50 & 0.02 & 0 & 1 \\
\hline
\end{tabular}

Notes: $N=612$. Results weighted by wtssnr.

only significant effect is that religious "others" are more interested in science than religious "nones." Individuals with higher levels of education report significantly higher levels of interest in science. It is difficult to know with cross-sectional data if an interest in science drives a person to acquire more education, or whether education exposes a person to science and increases their interest level. Finally, women show significantly lower science interest levels.

Turning next to the knowledge of science outcome, we again find that religiosity has no significant association with a respondent's knowledge of science. The only 


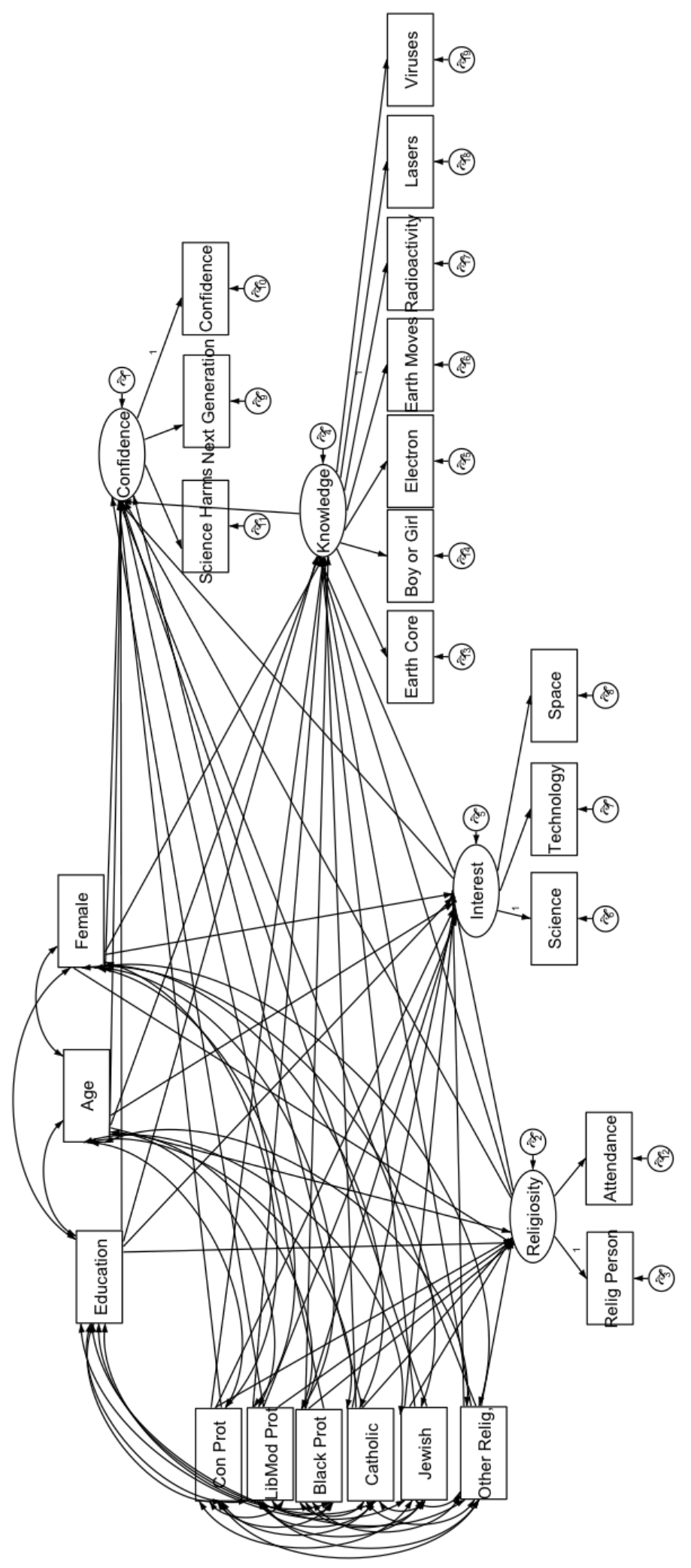

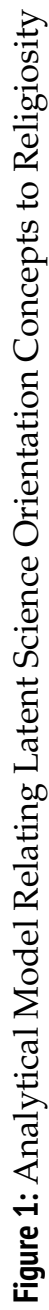


Table 2: Standardized Results from Structural Components of Analytical Model.

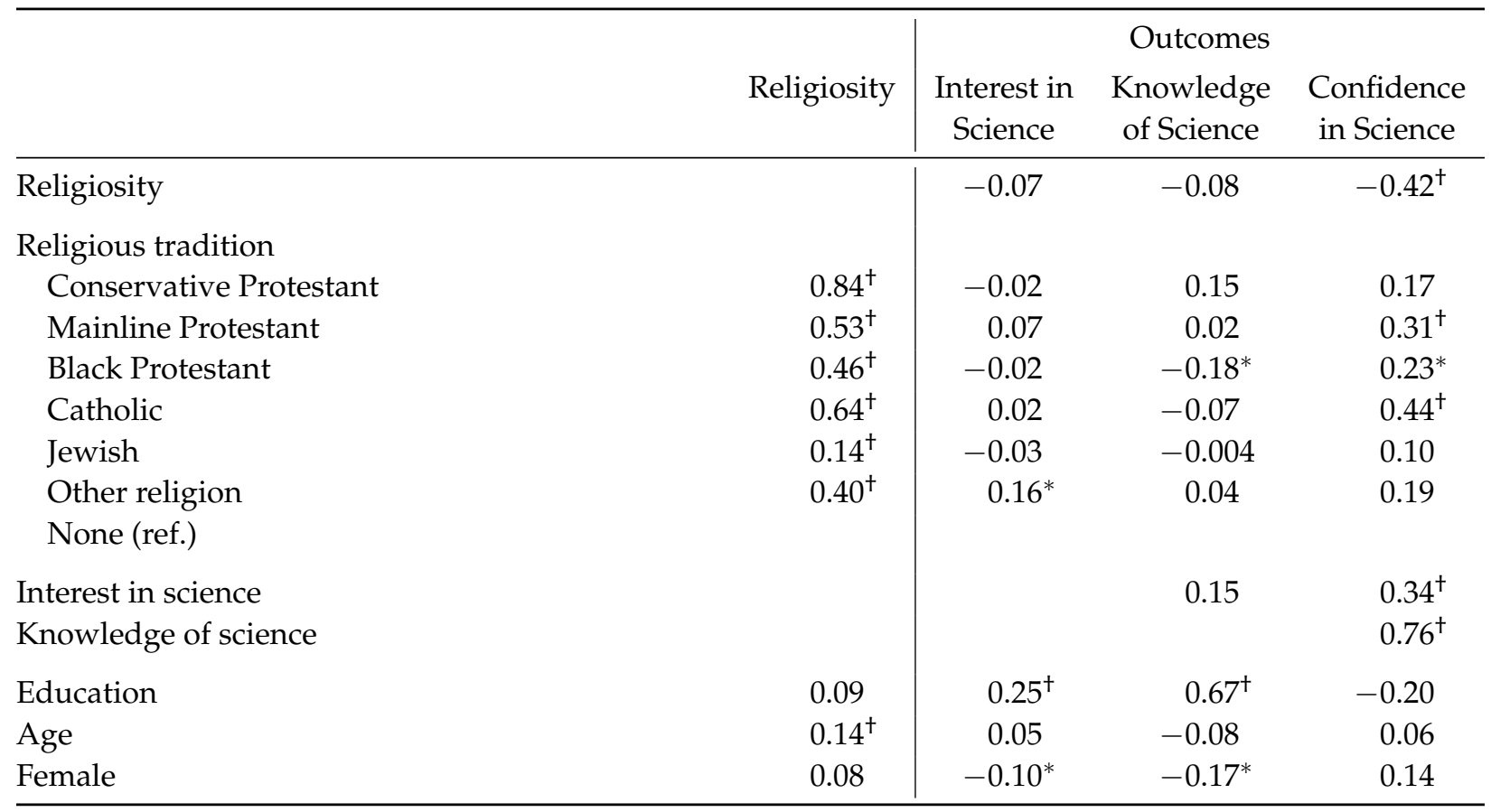

Notes: $N=612$. Results weighted by wtssnr. Fit statistics: Standardized root mean squared residual $=0.045$. Coefficient of determination $=0.901$.

$+p<0.01 ; * p<0.05$.

religious tradition effect is that black Protestants have lower levels of scientific knowledge relative to religious nones. Somewhat surprisingly, interest in science does not have a significant association with knowledge of science. Education has a very strong positive association with scientific knowledge, as would be expected. Older respondents do not show a significantly different knowledge of science, although women show a lower level of knowledge about science.

Finally, we examine the confidence in science outcome. Here we find that religiosity is significantly and negatively associated with confidence in science. However, mainline Protestants, Catholics, and black Protestants report higher levels of confidence in science than the religiously unaffiliated. Interest in and knowledge of science is significantly associated with greater confidence in science. None of the demographic measures have a significant direct effect on confidence in science, although education has an indirect effect through its association with increased interest in and knowledge of science.

To summarize the key findings, more religious individuals report the same interest levels and knowledge of science as less religious people, but they report significantly lower levels of confidence in science. This means that their lack of confidence is not a product of interest or ignorance but represents some unique uneasiness with science. We discuss these findings more below. 


\section{Discussion and Conclusion}

In thinking about religiosity's effects on an individual's orientation towards science, the how and why are not separate questions. Specifying how religiosity shapes orientation towards science is a central step in identifying why such an effect exists. However, attempts to answer these questions have often suffered from conceptual and empirical weaknesses. Research has not been precise enough in conceptualizing and operationalizing the complex nature of the orientation towards science concept, which has made addressing the how and why impossible. In the analysis presented above we try to take several steps towards answering these questions.

Specification of individual orientation to science is important because it enables more precise conclusions about the relationship between religion and science. The only study to have examined the link between religiosity and interest in science did so by examining propensity to major in science or engineering or to work in a scientific occupation (Evans 2011). Less than half of the U.S. population attends college (National Center for Education Statistics 2012), and only five percent of the U.S. labor force is composed of scientists and engineers (National Science Board 2012).

The central findings from our analysis produced just as many difficult questions as they provided answers. On the one hand, our analysis demonstrates that more religious individuals are not less interested in or less knowledgeable about science than others. Although Evans (2011) did not fully specify a model that included each of these measures, he arrived at a similar conclusion. These findings go against perceptions of religion as an obstacle to or repellant of scientific interest and knowledge. If we had found, however, that religiosity reduced these aspects of an individual's orientation towards science, then it might have made the significant negative effect of religiosity on confidence in science easier to explain. If a confidence gap could be explained through lack of information or interest, then we might have a clean explanatory narrative and a clear policy prescription for anyone interested in addressing this gap in confidence: we would have to get religious individuals and communities more involved in science so as to increase their interest in and knowledge of science. Our analysis, however, refutes the logic of this argument: interest in science has no significant association with knowledge of science. What is more, a significant confidence gap exists in the absence of any gap in interest or knowledge. We are left, then, to speculate on the how and why of this gap.

There may be signs of an answer to this puzzle in our individual indicators of confidence in science. Two of these measures, one asking whether science will bring more harm than good and the other asking whether science will provide more opportunities for future generations, appear to reflect individuals' optimism concerning what type of world science will create in the future. Religious individuals may be fully aware of the potential for material and physical gains through biotechnology, neuroscience, and other scientific advancements. Despite their knowledge of and interest in this potential, they may also hold deep reservations about the moral and spiritual costs involved. While more secular respondents may interpret a question about future harms and benefits from science in material terms (e.g., longer life expectancies versus more devastating weapons), religious individuals 
may interpret such questions as involving spiritual and moral harms and benefits. Concerns about these harms and gains are probably moderated by a perception, not entirely unfounded given the relatively secular nature of many in the academic scientific community (Ecklund and Scheitle 2007; Ecklund 2010), that the scientific community does not share the same religious values and therefore may not approach issues such as biotechnology in the same manner as a religious respondent. Indeed, our third measure of confidence in science asks about the respondent's confidence in the "scientific community," not science in the abstract.

Our findings also complicate existing understandings of the relationship between religious tradition and confidence in science. Evans (2011) found that only fundamentalist and evangelical protestants experience moral conflict with scientists, and only in cases regarding their influence in global warming issues and embryonic stem cell research. No other differences were found among religious denominations on these two issues or on scientists' influence on genetically modified food. Our analysis found that-net of religiosity, education, and other demographic measures-mainline Protestants, black Protestants, and Catholics have significantly higher levels of confidence in science than nonreligious individuals. It could be that there is something unique about religious affiliation within these groups, relative to other religious traditions, that offers greater integration with social institutions. This could in turn lead members of these traditions to have greater confidence in social institutions than members of other religious groups and nonreligious individuals.

There are, of course, limitations to our analysis and questions left unanswered.

Existing measures of science consumption in the GSS are limited, which hinders researchers' ability to model how religiosity may influence individual orientation to science. ${ }^{12}$ The GSS is also cross-sectional. Ideally, these measures would be assessed longitudinally to determine how religiosity and individual orientation to science unfold over time, particularly during early stages of the life course. Both limitations offer fertile terrain for future research.

Our results suggest in particular a need for more research to examine why individual religiosity matters for confidence in science, but not interest in or knowledge of science. For example, religious opposition to morally salient areas of scientific research such as genetic engineering are understandable given religious beliefs about the origins of life, but why are religious individuals skeptical of the potential for material and physical gains derived from less morally relevant areas of science? Such a question may best be pursued through qualitative research on religious understandings of science.

\section{Notes}

1 Ecklund, Park, and Veliz (2008) do not control for dimensions of science in a statistical sense because it is a qualitative piece. By exclusively sampling scientists, however, it does effectively account for meanings and dimensions of science.

2 One might also criticize the construct validity of their submeasure, "ability index," which may more readily represent consumption of science than ability, with its inclusion of educational background and reported informedness of science. Ability is best measured by quiz type questions, which are common in public understanding of science surveys. 
3 As Roos (2012) explains, these studies have contrasting results in part due to how Evans (2011) and Sherkat (2011) coded religious traditions, religious beliefs, and scientific knowledge.

4 We also examined the 2010 GSS as a potential data source, as it included many of the same science orientation items as the 2008 GSS. However, we found that the 2010 GSS prevented us from being able to include all of our concepts of interest because some items were asked of some respondents but not others. Enough of the 2008 GSS sample received all of the relevant items to allow for an analysis of all of our concepts of interest.

5 The 2008 GSS provides some potential consumption measures. Respondents were asked how many science courses they took in college, but consumption of college science courses is often the product of standardized curricula more than an independent desire to consume science. Respondents were also asked how often they visited a science museum in the past twelve months.

6 We use the SEM feature of Stata.

7 Other issues included agriculture and farm issues, environmental pollution, and military and defense policy, for example. Given that that the connection between science and these issues is not immediately obvious in the survey questions, we selected only those that best captured science.

8 We note here that the Sun/Earth question departs from the true/false pattern of the prior survey questions, but the shift does not appear to be to the detriment of survey respondents as one might expect. On average, 65 percent of survey respondents correctly answered true/false science questions in 2008, whereas 72 percent correctly answered the question regarding whether the earth travels around the sun.

9 Decades of research have relied upon knowledge questions to understand attitudes towards science, a precedent we follow. For a recent critique of this approach, see Rughinis (2011).

10 We did run a model with the "scientific community" item excluded from this latent variable, but this did not change the results in any significant way.

11 The syntax for creating these variables was acquired from: www . indiana. edu/ soc/pdf / RELTRADsyntax_3versions.pdf

12 In a separate analysis using museum attendance as a proxy for science consumption, we found that: individuals with higher interest levels in science have higher consumption levels of science; consumption of science is not associated with knowledge of science; and that consumption is not significantly associated with confidence in science. Nor does religiosity significantly affect consumption. Given that attending a museum is at best a weak proxy, we elected not to include it in our final analysis.

\section{References}

Allum, Nick, Patrick Sturgis, Dimitra Tabourazi, and Ian Brunton-Smith. 2008. "Science Knowledge and Attitudes across Cultures: A Meta-analysis." Public Understanding of Science 17(1):35-54. http://dx. doi .org/10.1177/0963662506070159.

Baker, Joseph O. 2012. "Public Perceptions of Incompatibility between Science and Religion." Public Understanding of Science 21(3):340-353. http://dx.doi .org/10.1177/ 0963662511434908.

Baker, David P. and Deborah P. Jones. 1993. “Creating Gender Equality: Cross-national Gender Stratification and Mathematical Performance." Sociology of Education 66(2):91-103. http://dx.doi.org/10.2307/2112795. 
Baron-Cohen, Simon. 2003. The Essential Difference: Men, Women and the Extreme Male Brain. New York: Basic Books.

Besley, John C. and James Shanahan. 2005. "Media Attention and Exposure in Relation to Support for Agricultural Biotechnology." Science Communication 26(4):347-67. http: //dx.doi.org/10.1177/1075547005275443.

Bouillon, Lisa M. and Louis M. Gomez. 2001. "Connecting School and Community with Science Learning: Real World Problems and School-Community Partnerships as Contextual Scaffolds." Journal of Research in Science Teaching 38(8):878-898. http: //dx.doi.org/10.1002/tea.1037.

Brickhouse, Nancy W. 1994. "Bringing in the Outsiders: Reshaping the Sciences of the Future." Journal of Curriculum Studies 26(4):401-416. http://dx.doi.org/10.1080/ 0022027940260404.

Brossard, Dominique, Dietram A. Scheufele, Eunkyung Kim, and Bruce Lewenstein. 2009. "Religiosity as a Perceptual Filter: Examining Processes of Opinion Formation about Nanotechnology." Public Understanding of Science 18(5):546-558. http://dx . doi . org/10 . $1177 / 0963662507087304$.

Cadge, Wendy, Elaine Howard Ecklund, and Nicholas Short. 2009. "Religion and Spirituality: A Barrier and a Bridge in the Everyday Professional Work of Pediatrics." Social Problems 56(4):702-21. http://dx.doi.org/10.1525/sp.2009.56.4.702.

Campbell, Robert A. 2005. "Students' Views on the Relationship between Science and Religion: Analyses of results from a Comparative Survey." Canadian Review of Sociology and Anthropology 42(3):249-265. http: //dx.doi .org/10.1111/j.1755-618X.2005. tb00839.x.

Condron, Dennis and Vincent Roscigno. 2003. “Disparities within: Unequal Spending and Achievement in an Urban School District." Sociology of Education 76(1):18-36. http: //dx.doi.org/10.2307/3090259. I smallskip

Correll, Shelley J. 2001. "Gender and the Career Choice Process: The Role of Biased Selfassessments." American Journal of Sociology 106(6):1691-1730. http://dx.doi .org/10 . $1086 / 321299$.

Darnell, Alfred and Darren E. Sherkat. 1997. “The Impact of Protestant Fundamentalism on Educational Attainment." American Sociological Review 62:306-315. http://dx.doi.org/ $10.2307 / 2657306$.

Dragojlovic, Nicolas and Edna Einsiedel. 2012. "Playing God or Just Unnatural? Religious Beliefs and Approval of Synthetic Biology." Public Understanding of Science 22(7):869-885. http://dx.doi.org/10.1177/0963662512445011.

Ecklund, Elaine Howard. 2010. Science vs. Religion: What Scientists Really Think. Oxford: Oxford University Press. http://dx.doi.org/10.1093/acprof : oso/9780195392982. 001.0001.

Ecklund, Elaine Howard and Christopher P. Scheitle. 2007. "Religion among Academic Scientists: Distinctions, Disciplines and Demographics." Social Problems 54(2):289-307. http://dx.doi.org/10.1525/sp.2007.54.2.289.

Ecklund, Elaine Howard and Jerry Z. Park. 2009. "Conflict between Religion and Science among Academic Scientists?" Journal for the Scientific Study of Religion 48(2):276-92. http://dx.doi.org/10.1111/j.1468-5906.2009.01447.x.

Ecklund, Elaine Howard, Jerry Z. Park, and Phil Todd Veliz. 2008. "Secularization and Religious Change among Elite Scientists." Social Forces 86(4):1805-1839. http://dx. doi . org/10.1353/sof.0.0048. 
Ellison, Christopher G. and Marc A. Musick. 1995. "Conservative Protestantism and Public Opinion toward Science." Review of Religious Research 36(3):245-262. http://dx. doi . org/10.2307/3511533.

Evans, John H. 2011. "Epistemological and Moral Conflict between Religion and Science." Journal for the Scientific Study of Religion 50(4):707-727. http://dx. doi .org/10.1111/j . 1468-5906.2011.01603.x.

Evans, John H. and Michael Evans. 2008. "Religion and Science: Beyond the Epistemological Conflict Narrative." Annual Review of Sociology 34(1):87-105. http://dx.doi .org/10 . 1146/annurev.soc.34.040507.134702.

Evans, Michael S. 2012. "Supporting Science: Reasons, Restrictions, and the Role of Religion." Science Communication. 34(3):334-362. http://dx.doi.org/10.1177/ 1075547011417890.

Evans, Geoffrey and John Durant. 1995. "The Relationship between Knowledge and Attitudes in the Public Understanding of Science in Britain." Public Understanding of Science 4(1):57-74. http://dx.doi .org/10.1088/0963-6625/4/1/004.

Gieryn, Thomas. 1983. "Boundary-Work and the Demarcation of Science from Non-science: Strains and Interests in Professional Ideologies of Scientists." American Sociological Review 48(6):781-795. http://dx.doi.org/10.2307/2095325.

Gauchat, Gordon. 2008. "A Test of Three Theories of Anti-science Attitudes." Sociological Focus 41(4):337-57. http: //dx. doi .org/10.1080/00380237.2008.10571338.

Gauchat, Gordon. 2012. "Politicization of Science in the Public Sphere: A Study of Public Trust in the United States, 1974 to 2010." American Sociological Review 77(2):167-187. http://dx.doi.org/10.1177/0003122412438225.

Gross, Neil and Solon Simmons. 2009. "The Religiosity of American College and University Professors." Sociology of Religion 70(2):101-129. http://dx.doi.org/10.1093/socrel/ srp026.

Harnisch, Delwyn 1984. "Females and Mathematics: A Cross-National Perspective." Pp. 73-91 in Advances in Motivation and Achievement Volume 2, edited by Martin Maehr. Greenwich, Conn: JAI Press.

Hayes, Barbara C. and Vicki Tariq. 2000. "Gender Differences in Scientific Knowledge and Attitudes toward Science: A Comparative Study of Four Anglo-American Nations." Public Understanding of Science 9(4):433-47. http: //dx . doi .org/10 . 1088/0963-6625/9/ $4 / 306$.

Ho Shirley S, Dominique Brossard, and Dietram A Scheufele. 2008. "Effects of Value Predispositions, Mass Media Use, and Knowledge on Public Attitudes toward Embryonic Stem Cell Research." International Journal of Public Opinion Research 20(2):171-92. http: //dx.doi.org/10.1093/ijpor/edn017.

Holton, Gerald. 1993. Science and Anti-Science. Cambridge, MA: Cambridge University Press.

Kelly, Alison. 1985. "The Construction of Masculine Science." British Journal of Sociology of Education, 6(2):133-154. http://dx.doi.org/10.1080/0142569850060201.

Kelly, Alison, Barbara Smail, and Judith Whyte. 1984. Initial GIST Survey: Results and Implications. Manchester, UK: Manchester Polytechnic.

Kirby, James B. and Toshiko Kaneda. 2005. “Neighborhood Socioeconomic Disadvantage and Access to Health Care." Journal of Health and Social Behavior 46(1):15-31. http: //dx.doi.org/10.1177/002214650504600103.

Lee, Okhee and Sandra H. Fradd. 1998. "Science for All, Including Students from NonEnglish-Language Backgrounds." Educational Researcher 27(4):12-21. http://dx.doi . org/10.3102/0013189x027004012. 
Losh Susan C. 2011. “American Public Understanding of Science: 1979-2006." Pp. 55-75 in The Culture of Science: How the Public Relates to Science Across the Globe, edited by Martin W. Bauer, Rajesh Shukla, and Nick Allum. New York: Routledge.

Merton, Robert. 1968. Social Theory and Social Structure. New York: Free Press.

Miller, Jon D. 1991. The Public Understanding of Science and Technology in the United States. Washington: National Science Foundation.

Miller, Jon D., Rafael Pardo and Fujio Niwa. 1997. Public Perceptions of Science and Technology: A Comparative Study of the European Union, the United States, Japan, and Canada. Chicago:Chicago Academy of Sciences.

National Center for Education Statistics. 2012. Digest of Education Statistics, 2011. U.S. Department of Education (NCES 2012-001).

National Science Board. 2012. Science and Engineering Indicators 2012. Arlington, VA: National Science Foundation (NSB 12-01).

Nisbet Matthew C. 2005. "The Competition for Worldviews: Values, Information, and Public Support for Stem Cell Research." International Journal of Public Opinion Research 17(1):90-112. http://dx.doi.org/10.1093/ijpor/edh058.

Peng, Samuel and Jay Jaffe. 1979. “Women Who Enter Male-dominated Fields of Study in Higher Education." American Education Research Journal 16(3):285-93. http://dx.doi. org/10.3102/00028312016003285.

Roos, J. Micah. 2012. “Measuring Science or Religion? A Measurement Analysis of the NSF Sponsored Science Literacy Scale 2006-2010." Public Understanding of Science 23(7):797813. http://dx.doi.org/10.1177/0963662512464318.

Rughinis, Cosima. 2011. “A Lucky Answer to a Fair Question: Conceptual, Methodological, and Moral Implications of Including Items on Human Evolution in Scientific Literacy Surveys." Science Communication 33:501-532. http://dx.doi.org/10.1177/ 1075547011408927.

Scheitle, Christopher P. 2011. "Religious and Spiritual Change in College: Assessing the Effect of a Science Education." Sociology of Education 84(2):122-136. http: //dx. doi .org/ $10.1177 / 0038040711401811$.

Scheufele, Dietram, Elizabeth Corley, Tsung-jen Shih, Kajsa E. Dalrymple, and Shirley S. Ho. 2008. "Religious Beliefs and Public Attitudes toward Nanotechnology in Europe and the United States." Nature Nanotechnology 4:91-4. http://dx. doi .org/10.1038/nnano. 2008.361.

Sherkat, Darren E. 2011. "Religion and Scientific Literacy in the United States." Social Science Quarterly 92(5):1134-1150.

Smith, Christian and Patricia Snell. 2009. Souls in Transition: The Religious and Spiritual Lives of Emerging Adults. New York: Oxford University Press. http://dx.doi.org/10.1093/ acprof : oso/9780195371796.001.0001.

Steensland, Brian, Jerry Z. Park, Mark D. Regnerus, Lynn D. Robinson, W. Bradford Wilcox, and Robert D. Woodberry. 2000. "The Measure of American Religion: Toward Improving the State of the Art." Social Forces 79(1):291-318. http://dx.doi.org/10.1093/sf/79.1. 291.

Sturgis, Patrick and Nick Allum. 2004. "Science in Society: Re-evaluating the Deficit Model of Public Attitudes." Public Understanding of Science 13(1):55-74. http://dx .doi .org/10 . $1177 / 0963662504042690$.

Wynne, Bryan. 1991. "Knowledges in Context." Science, Technology, and Human Values 16(1):111-121. http://dx.doi.org/10.1177/016224399101600108. 
Yearley, Steven. 2000. Making Sense of Science. London: Sage.

David R. Johnson: Department of Sociology, Rice University. E-mail: drj4@rice.edu.

Christopher P. Scheitle: Department of Sociology, St. John's University. E-mail: cscheitle@csbsju.edu.

Elaine Howard Ecklund: Department of Sociology, Rice University. E-mail: ehe@rice.edu. 